Portland State University

PDXScholar

\title{
Vestiges of Propaganda: Postage Stamps Issued by the Third Reich in Poland and the Netherlands During the Second World War
}

Olivia Phillips

Portland State University

Follow this and additional works at: https://pdxscholar.library.pdx.edu/honorstheses

Part of the European History Commons, Holocaust and Genocide Studies Commons, Political History Commons, and the Social History Commons

Let us know how access to this document benefits you.

\section{Recommended Citation}

Phillips, Olivia, "Vestiges of Propaganda: Postage Stamps Issued by the Third Reich in Poland and the Netherlands During the Second World War" (2021). University Honors Theses. Paper 1099.

https://doi.org/10.15760/honors.1126

This Thesis is brought to you for free and open access. It has been accepted for inclusion in University Honors Theses by an authorized administrator of PDXScholar. Please contact us if we can make this document more accessible: pdxscholar@pdx.edu. 
Vestiges of Propaganda: Postage Stamps issued by the Third Reich in Poland and the Netherlands during the Second World War

by

Olivia Phillips

An undergraduate honors thesis submitted in partial fulfillment of the requirements for the degree of

Bachelor of Arts

in

University Honors

and

History

Thesis Adviser

Kathleen Merrow

Portland State University

2021 


\section{Table of Contents}

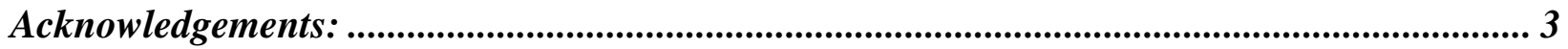

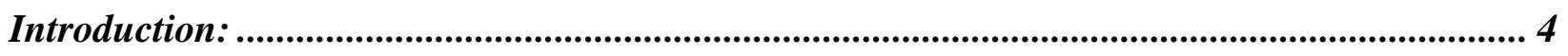

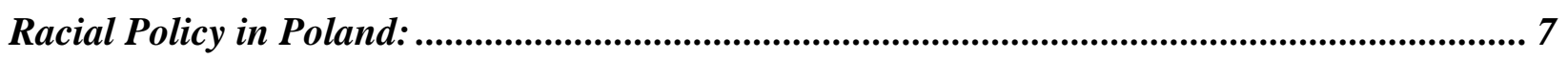

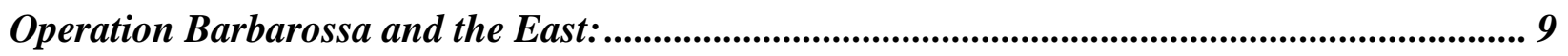

Stamp Reissues and Overprints and the Post Office in War:.............................................. 12

German Colonialization of the East: ....................................................................................... 10

The Netherlands and the Aryan Question: ................................................................................... 14

National Socialist Art and Propaganda: ............................................................................ 16

The Reichpost :.............................................................................................................................. 19

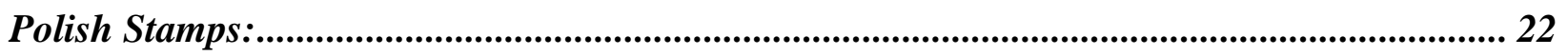

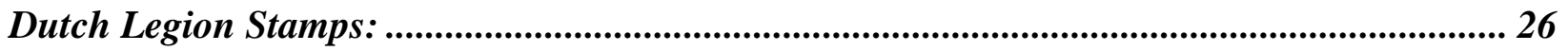

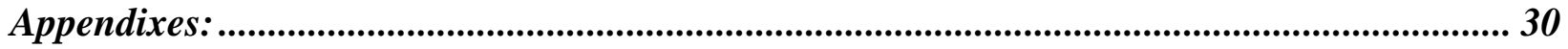

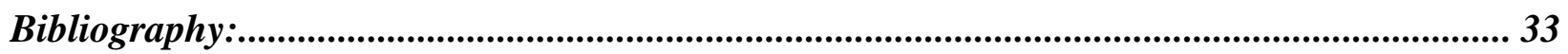




\section{Acknowledgements:}

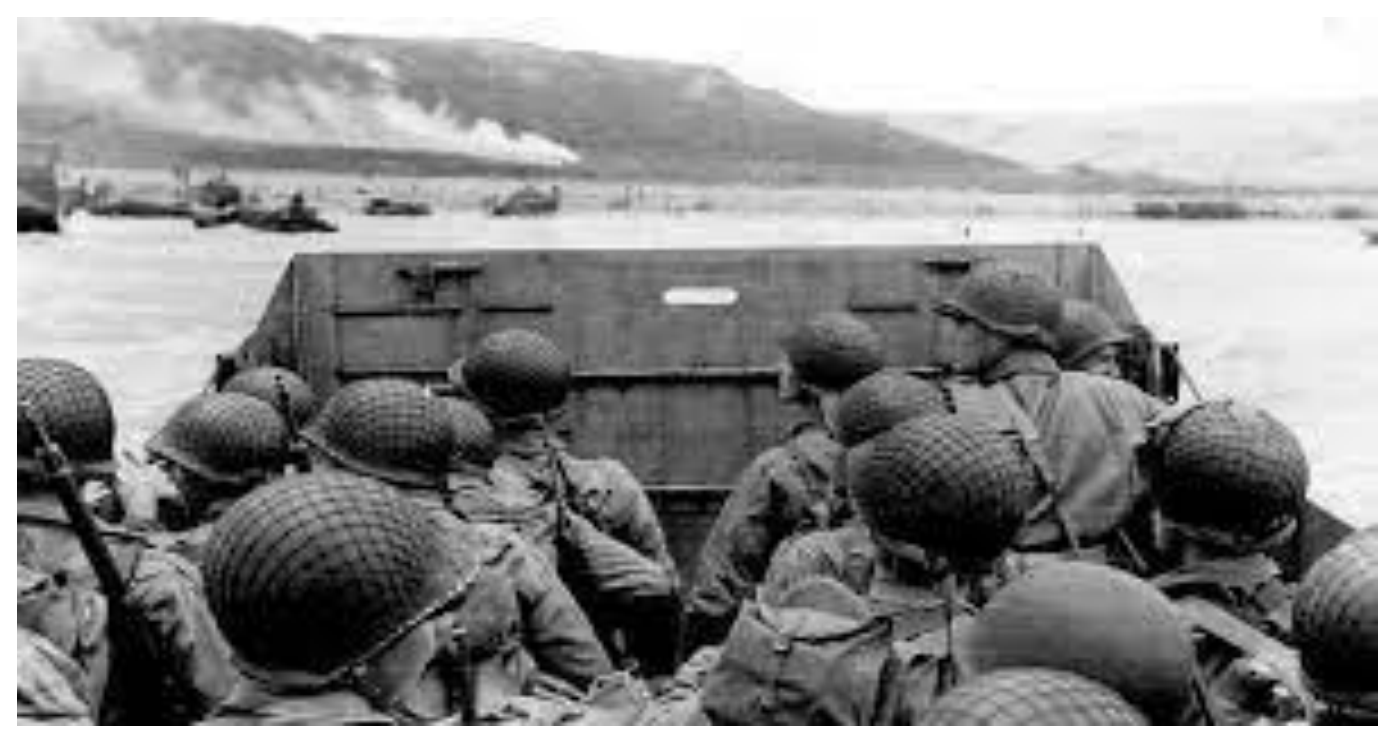

I would like to dedicate this thesis to my grandfather Clarence "Buster" Allen. He died sadly before I was born but his story of service to our great nation inspired my passion for history. My grandfather did not speak much about his service during the Second World War, nor his time he spent in the Korean war but after his death we found this photo of him landing on the beaches of Normandy. He is at the helm of the ship in the upper right-hand corner on his way to liberate Europe from great tyranny. He served in the Second Infantry where he fought his way through D-Day, the Battle of the Bulge and Germany. During his time in Europe, he and his men liberated concentration camps, cities, and towns in western Europe, nearly froze to death in the Ardennes Forest where he went without winter clothing or sufficient ammunition and fought hand to hand combat. It is truly a miracle of what he lived through and is a testament to the fortitude of America's greatest generation. My grandfather only had a fifth-grade education, but he served his nation with courage, was a proud father, and a hard worker. He is my guardian angel, and I will forever be thankful to have him as my grandfather.

I would also like to thank my parents for not only their love and support but also for the dedication towards my education and the sacrifices they made for me. They continued to fuel my passion for history and without their support I would not be the woman I am today. I am blessed to call them my parents.

I would be remissed not to mention my thesis advisor Dr. Kathleen Merrow, as well as the professors and librarians at Portland State University, Bryn Mawr and Haverford Colleges as well as my teachers at Catlin Gabel who continued to support my academic work and interests. 


\section{Introduction:}

The idea for this thesis came to me while I was sitting at my dining room table working on my stamp collection. I methodically sorted through an assortment of vintage stamps and used

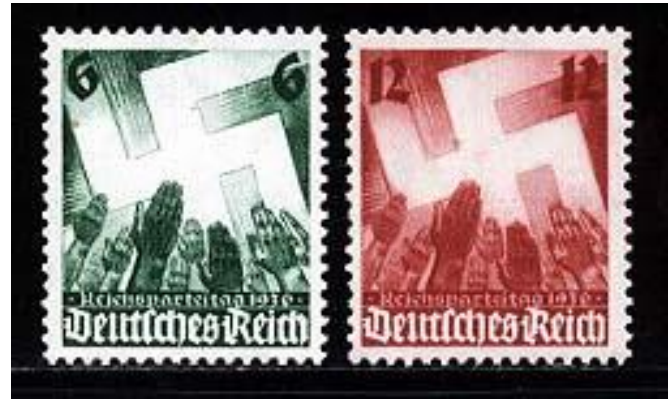

stamp tweezers, to gently affix stamp hinges to the back of the stamps where I then placed them into my stamp album. As I sorted through the miscellaneous stamps — a particular stamp caught my eye. ${ }^{1}$ The stamp was a 1936 German stamp, issued by the Reichpost. The stamp showed a crowd raising their hand in the Nazi salute with a giant swastika in the background. The magnitude of the image was not lost on me, and the strident imagery of a symbol of wanton hate pierced into my vision. Measuring only an inch by three quarters of an inch this stamp helped to embody the terror, the cult of personality, and magnitude that the National Socialist Workers Party (Nationalsozialistische Deutsche Arbeiterpartei) had on the world. After finding this stamp I began to research other stamps that were produced by the Third Reich, and I became fascinated by the bold, and off-putting stylized images that were printed. I soon became dismayed, when I saw that while philatelists had spent considerable time on the cataloging and the research of such stamps, a predominant majority of historians had simply side stepped this important piece of history. ${ }^{2}$ But it was not only Reichpost stamps that

\footnotetext{
${ }^{1}$ All Stamps. "Nazi Party Congress 1936," n.d. https://www.allstamp.net/product/GE00047980.html.

${ }^{2}$ I would be remised if I did not mention the scholars who have conducted excellent research into postal history and philately. Please find a selected few of my favorite sources below:

Frederick Dost. World Maritime History Lessons Through Postage Stamps. Frederick E. Dost, 2015.

Fred Mellville, The Postage Stamp in War: Illustrated Edition. London: Echo Library, 2015. Albert Moore. 2003. Postal propaganda of the Third Reich. Atglen, PA: Schiffer Military History. Gates, Robin Elliot. "Philatelic Propaganda: A Case Study_Border Changes in Eastern Europe, 1938-1941." Smithsonian Institution Scholarly Press, 2010.

Ronald Eisenberg. 2002. The Jewish world in stamps: 4000 years of Jewish civilization in postal stamps. Rockville, Md: Schreiber Pub.

Henrik, Eberle, Victoria Harris, and Steven Rendall. Letters to Hitler. Cambridge; Malden, Ma.: Polity, 2012.
} 
were ignored by historians as virtually all postal history has been neglected by the academic community. Stamps and postal systems played a prominent role in the development of countries across the world and helped to create the world that we know today. ${ }^{3}$ After seeing the lack of data and information that had been produced on stamps issued by the Third Reich, I decided that as a historian my goal would be to bridge the gap between philatelists and historians, and highlight the important role in which postage stamps played during the Second World War.

In an age where digital technology dictates the way in which we live our lives, it is easy to forget the important role that post offices played in twentieth century society, as almost every man, woman and child who were literate relied on some form of postal communications. Some scholars have researched how post offices can be used to track the development of a nation. This idea is illustrated by the scholars Rogowski, Gerring, and Cojocaru, who have paid particular attention into how a nation's postal systems impact their development. These scholars state,

We theorize that the establishment and/or expansion of government-run postal systems in the nineteenth century generated short- and long-run economic effects by (a) reducing transaction costs, (b) facilitating the discussion of ideas and technology, and (c) strengthening social capital. ${ }^{4}$

Other social and developmental historians have also researched the ways in which post offices across the world have drastically influenced society. The communication theorist Lucian Pye, who is a political scientist that focuses on the intersectionality between political science and communication structures furthers expands on this theory. He highlights this by writing, The communications process provides a basis for limiting and making explicit the legitimate scope of political causality so that leaders and citizens can all be compelled to

Keith Jeffery. "Crown, Communication and the Colonial Post: Stamps, the Monarchy and the British Empire." The Journal of Imperial and Commonwealth History 34, no. 1 (March 2006): 45-70. https://doi.org/10.1080/03086530500411290.

${ }^{3}$ In Neither Snow nor Rain by Devin Leonard, he tracks how the United States Post Office was the founder of modern-day commercial aviation, and drastically helped create the web of highways across the United States.

${ }^{4}$ Jon C Rogowski, John Gerring, and Lee Cojocaru, "Infrastructure and Development: Evidence from Postal Systems," 2017, 2. 
accept the same sense of the plausible. At the same time, by identifying the appropriate rules of responsibility, it can hold the political actors tightly in a web of causality. ${ }^{5}$ While Pye's theory is used to determine broader structures of communications theory, it is easy to understand how Pye's argument is applicable to postal communications theory and the strategies that a regime might employ to legitimize their rule over a society. Thus, the images on postage stamps further help to emphasize the policies employed by the Third Reich and allow for historians to have a first-hand glimpse of propaganda and how it was utilized in Germany and the countries it occupied during the Second World War.

Throughout this paper I will question how stamps that were issued by the Reichpost in Poland and the Netherlands portray the racial and colonial policies that were utilized by the Nazi regime? I will argue that the Reichpost was an extension of the Reichsministerium für Volksaufklärung und Propaganda (RMVP) and worked to rewrite Polish history through the Germanification of Polish landmarks. While in the Netherlands, the stamps that were issued portray the same aesthetics of hypermasculinity and the idea of Blot und Boden, as in Nazi Germany. The differentiation between these two country's stamps helps to highlight different iterations of Nazi racial policy, which saw the Dutch classified as Aryan and the Polish people who were classified as Untermenschen. I will support my argument by introducing historical background of Nazi racial policy and the Nazi occupation of Europe, before focusing the discourse community on art and culture in the Third Reich. I will then discuss general themes of Nazi art and before highlighting how they were utilized in the stamps that were produced in these occupied countries.

\footnotetext{
${ }^{5}$ Lucian W. Pye, Communications and Political Development. (SPD-1) (Princeton, UNITED STATES: Princeton University Press, 1963), http://ebookcentral.proquest.com/lib/psu/detail.action?docID=4339554, 7.
} 


\section{Racial Policy in Poland:}

To understand the different manifestations of the Nazi final solution it is necessary to focus on their racial policy. Hitler virulently scatters anti-Semitic tropes in his memoir Mein Kampf. A particularly poignant quote helps to establish how the Nazis would center their regime on hatred and terror. Hitler writes,

If, with the help of his Marxist creed, the Jew is victorious over the other peoples of the world, his crown will be the funeral wreath of humanity and this planet will, as it did thousands of years ago, move through the ether devoid of men. ${ }^{6}$

The Nuremberg Laws of 1935 are an early example of the racial anti-Semitic policy that was central to the Third Reich. These laws detail the eugenic and racially based purity laws that were put into place to protect the German race. ${ }^{7}$ Before we delve deeper into the racism that was central to the Nazi regime, it is necessary to detangle the many different terms that were used by the Nazis to describe their creation of a pure master race. Those terms include Aryan, Aryanization, Germanization, subhuman, Untermenschen, Herrenvolk, and Herrenrasse. The term Aryan, which many people associate with Nazi policy, was a term that the Nazis used to depict their supposed ethnic race. However, the Nazis misappropriated this term from ethnic and cultural anthropologists and retooled the meaning to define people of Nordic and Germanic ancestry. Throughout this essay I will describe the Germanization of Polish society, instead of using the term Aryan. ${ }^{8}$ The Aryanization of society usually means the eradication of the Jewish people from a countries culture. Because we are focusing on Poland, I will use the term Germanization, which I will define here as the eradication and subjugation of ethnic

\footnotetext{
${ }^{6}$ Adolf Hitler, Murphy, James Vincent, and Carruthers, Bob. Mein Kampf : The Official 1939 Edition. Hardback ed. Arden, Warwickshire: Coda Books, 2011, 60.

7 "The Law for the Safegaurd of German Honor," September 15, 1935, http://multivu.prnewswire.com/mnr/archives/45819/docs/45819-Translation-Blood_and_Honor.pdf.

${ }^{8}$ Kieran Allen, "The Sociologist of Empire," in Weber, 2nd ed., Sociologist of Empire (Pluto Press, 2017), 15-31, https://doi.org/10.2307/j.ctt1v2xw28.5, 12
} 
Poles from Poland. I will also use the term Herrenrasse (master race) to describe the master race of people who the Nazis defined as Aryan. ${ }^{9}$

The Nuremberg laws are only such one iteration of the Nazi's racial policy, which began to seep into all aspects of German society. But it was not only the Jewish people who would suffer under the yoke of Nazi oppression — the Poles were also considered to be Untermenschen, a German term used to codify people who were subhuman and who did not fit into the racially pure laws of the Third Reich. The intermixing between the Polish and the German people is highlighted in the pages of Mein Kampf. Hitler states,

Polish people could be Germanized by being compelled to use the German language. The result would have been fatal. A people of foreign race would have had to use the German language to express modes of thought that were foreign to the German, thus compromising by its own inferiority the dignity and nobility of our nation. ${ }^{10}$

The Nazis racial policy was closely affiliated with their colonial policy as they worked to expand the greater German Reich. In order to create a master race, the German's needed to create more space for industry and arable land for the growth of crops to be used by the German people. This is where we see the induction of the idea of Lebensraum. The esteemed Holocaust historian, Saul Friedländer, helps to highlight and focus in on the Nazi's policies. He writes,

The crimes committed by the Nazi regime were neither a mere outcome of some haphazard, involuntary, imperceptible, and chaotic onrush of unrelated events nor a predetermined enactment of a demonic script; they were the results of converging factors, of the interactions between intentions and contingencies, between discernible causes and change. General ideological objectives and tactical policy decisions enhanced one another and always remained open to more radical moves as circumstances changed. ${ }^{11}$

\footnotetext{
${ }^{9}$ STEPHEN G. FRITZ, "Emergence of the Idea," in The First Soldier, Hitler as Military Leader (Yale University Press, 2018), 18-38, https://doi.org/10.2307/j.ctv7cjw22.8, 33.

${ }^{10}$ Hitler, Mein Kampf, 323.

${ }^{11}$ Saul Friedländer, Nazi Germany and the Jews: The Years of Persecution, 1933-1939 (New York, N.Y.: Harper Perennial, 1997), 5.
} 
As we examine Nazi policy it is important to keep this quote in mind as it is easy to try and oversimplify history. The goal of this project is to see how such stamps interacted with the policy of the Third Reich.

\section{The Third Reich and the East:}

The invasion of Poland was the catalyst of change that helped to drag the world into

World War Two, however, the planned invasion of Poland on September 1st was a preplanned invasion in conjunction with the Union of Soviet Socialist Republics (USSR). Throughout 1939 the USSR and Germany engaged in diplomatic discussions about the normalization of relations, as well as the Polish national question. These discussions can be seen in the telegrams and official communications between different German ambassadors, trade attaches, and government officials, with the inevitable culmination being The Molotov-Ribbentrop in August of 1939. ${ }^{121314}$ However, these relations inevitably deteriorated, leading the Third Reich to annex the remainder of Poland from the USSR and declare war on the Soviets. ${ }^{15}$ For the scope of this analysis, I will be focusing on stamps that were issued in Poland after the Third Reich's successful occupation of Poland. During the invasion of Poland, the Soviets and the USSR issued a flurry of stamps to their newly annexed territory. A predominant majority of these stamps were either reprinted Polish stamps or reissued German postage stamps. ${ }^{16}$

\footnotetext{
12 “The Molotov-Ribbentrop Pact,” August 23, 1939, Internet Modern History Sourcebook, https://sourcebooks.fordham.edu/mod/1939pact.asp.

13 "The State Secretary in the German Foreign Office (Weizsäcker) to the German Ambassador in the Soviet Union (Schulenburg)," June 30, 1939, Purdue, http://www.ibiblio.org/pha/nsr/nsr-01.html\#2.

${ }^{14}$ Schnurre, "Foreign Office Memorandum," July 20, 1939, Purdue, http://www.ibiblio.org/pha/nsr/nsr-01.html\#2.

15 Joachim Ribbentrop, "The Reich Foreign Minister to the German Ambassador in the Soviet Union (Schulenburg)," June 21, 1941, Purdue, http://www.ibiblio.org/pha/nsr/nsr-09.html\#23.

16 “General Government - Postage Stamps - 1939 - German Empire Postage Stamps Surcharged \& Overprinted 'Deutsche Post OSTEN,'” accessed May 16, 2021, https://www.stampworld.com/stamps/General-

Government/Postage-stamps/g0001//.
} 


\section{German Colonialization of the East:}

The Third Reich sought to exploit Poland's natural resources, which help set in motion the process of Lebensraum. Due to the concentration of Jewish people living within the Polish state as well as the Polish people being consideredUntermenschen by the Nazis meant that Poland was ripe for the plunder. Due to Poland's subjugated status within the Third Reich's Empire, the Nazis were able to imperialize and colonize Poland. Numerous historians such as Mark Mazower and Timothy Snyder have examined this theory of the Third Reich's colonization in Eastern Europe. The historian David Furber helps to detangle our traditional held views of colonialism and its context within Eastern Europe. He writes,

First, as colonialism involves conquest and occupation, whether or not the rule lasts a long time, the intention to occupy permanently implies ownership of or trusteeship for the conquered people's land. Second, the colonizer's local political structure is dependent upon the imperial centre: the legal relationships between the two is less important than the fact that the expatriate rulers consider themselves to be living in a foreign land. Third, the colonizer a distinguishable by modernity, civilization, race, and respectability. The colonizer, who encounters conditions that offend, and even threaten by reminding him of characteristics he believes he has overcome, obtains a position of pseudo-aristocratic social privilege unattainable at home. ${ }^{17}$

This is the very crux of my argument for my thesis, as I will examine the differences between stamps issued in the Netherlands and the stamps that were issued in Poland. Poland was ruled by a de facto military regime called General Government. The Nazis had a specific plan, called the Generalplan Ost, which sought to rid Poland and other Eastern territories of their natural inhabitants and repopulate them with Aryans. ${ }^{18}$ This is why we also see a majority of concentration camps and death camps in the eastern reaches of the Third Reich-a policy of sublimination of the Slavic and Jewish people. This policy of subjugation is once again highlighted by Furber, who states,

\footnotetext{
${ }^{17}$ David Furber, "Near as Far in the Colonies: The Nazi Occupation of Poland," The International History Review 26, no. 3 (2004): 547-548.

${ }^{18}$ Ibid, 549.
} 
The rulers, forming a minority, are expatriates from a 'mother country' that claims the colony as its exclusive property. Colonialism is the relationship between the minority rulers and majority ruled. Dependent on the imperial centre for their authority, the foreign rulers make their decisions mainly in the interest of the empire rather than the colonial subjects. Similarly, the rulers resist the natural process of acculturation into the host culture because they hold it, if attractive in some respects, generally inferior. Thus, they feel a 'mandate' or 'mission' to change the culture or landscape of the colony to better suit their needs. ${ }^{19}$

The people of Poland did not matter for the Germans, only if they could be enslaved as laborers, or farm workers to better help the expansion of the Third Reich.

What is important to realize is that portions of Poland who had significant numbers of ethnic Germans would be repatriated back to the Third Reich after the success of operation Barbarossa. While territories in the eastern reaches of Poland would become part of the Ost Reich, who would be ruled over by the General Government. ${ }^{20}$ In fact, Hans Frank, who was the head of the General Government within Poland, admitted to how Poland would be used as a colony. In evidence that was given in the Nuremberg Trials, Franks describes the Nazi's policy

as,

Poland can only be administered by utilizing the country through means of ruthless exploitation, deportation of all supplies, raw materials, machines, factory installations, etc., which are important for the German war economy, availability of all workers for work within Germany, reduction of the entire Polish economy to absolute minimum necessary for bare existence of the population, closing of all educational institutions, especially technical schools and colleges in order to prevent the growth of the new Polish intelligentsia. 'Poland shall be treated as a colony; the Poles shall be the slaves of the Greater German World Empire. ${ }^{21}$

Thus, through the elicited testimony that was presented during the Nuremberg trials, we can see how Poland was being treated as a colony and was not being integrated into the empire and this differentiation can be seen in the stamps that were issued by the General Government.

\footnotetext{
${ }^{19}$ Ibid, 547

${ }^{20}$ Ibid, 550

${ }^{21}$ United States Office of Chief of Counsel for the Prosecution of Axis Criminality, Nazi Conspiracy and Aggression (U.S. Government Printing Office, 1946), 1025.
} 


\section{Stamp Reissues and Overprints and the Post Office in War:}

Stamp reissues or overprints are an important aspect of a nation's postal history and need to be examined by postal historians. According to Linns, a postal newspaper, "Surcharges are specifically related to the face value of a stamp. For example, if there is a postal rate increase, some countries choose to revalue a stamp of a different denomination by printing a new value on the top of, or adjacent to, the old value." ${ }^{22}$ Stamp surcharges or reissues can be used when a country comes under control of a new cabinet or parliament, or during times of inflation. This is
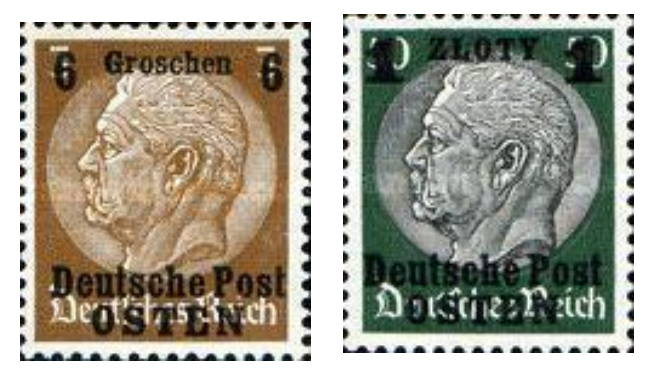
also a common theme in countries that were colonized, imperialized, or invaded during times of war. In the images to the left, we see two examples of stamp surcharges. Both stamps from 1939 are stamps that had originally been issued in German in 1934 and depict Paul von Hindenburg. Hindenburg was the president of Germany until his death in 1934 . These stamps were used because they did not configure to the new aesthetics of the Reichpost which was now being used as extension for the RMVP. These stamps further help to highlight how important postage stamps are in determining a regimes stability and legitimacy. Since these stamps were issued before Germany had begun its invasion of Soviet occupied Poland, the stamps were marked with Deutsche Post Osten.

In 1940 the General Government, the regime that rule over Poland, began to issue stamp reprints. The three stamps pictured below are Reichpost stamp reprints. The Germans in this iteration of a stamp reprint used a 1938 Polish stamp issue, which celebrated the $20^{\text {th }}$ anniversary of the Polish state. ${ }^{23}$ As seen below the General Government stamp skillfully covers any

\footnotetext{
${ }^{22}$ Janet Klug, "Surcharges and Overprints Make a Difference," Linns Stamp News, accessed May 1, 2021, https://www.linns.com/news/postal-updates-page/stamp-collecting-basics/2002/june/surcharges-and-overprintsmake-a-difference-.html.

23 "Poland - Postage Stamps - 1938 - The 20th Anniversary of the Republic," accessed June 9, 2021, https://www.stampworld.com/stamps/Poland/Postage-stamps/g0295//.
} 
identification of the country of Poland with the Reichsadler, which was the imperial Nazi seal. This stamp clearly highlights that Poland was being occupied by the Nazi regime who was working to eradicate Polish history.

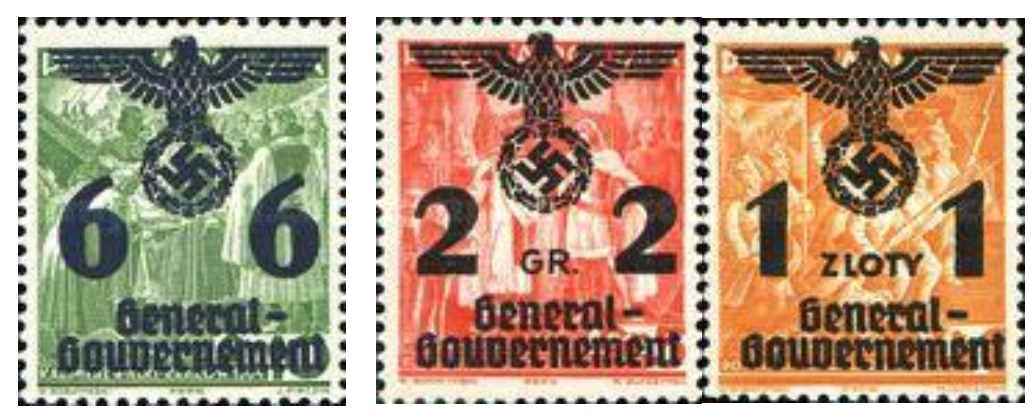

Over 15 million stamps were issued by the occupying forces, which illustrates the magnitude in which these stamps were dispersed and used..$^{24}$ The Nazi regime worked quickly to establish itself as a legitimate government through the reissuance of stamps. This idea of a regimes using the post office in order to validate its rule is further exemplified once again by the communication theorist, Pye, who states,

Another function of the communications process is to provide the essential basis for rationality in mass politics. A people can sensibly debate their collective actions only if they share a common fund of knowledge and information. And only if they have some minimum appreciation of how others have been informed about the state of affairs can citizens decide upon the wisdom and the validity of the reasoning behind the actions of their leaders. ${ }^{25}$

Thus, when Poland was annexed by the Third Reich and the USSR, the Nazis needed to establish the legitimacy of their regime, and they did this through the enaction and creation of an efficient postal apparatus. The postal system was used by all those who were literate, which was a large swath of the population in $1939 .^{26}$

\footnotetext{
24 Ibid.

25 Pye, Communications and Political Development, 6.

${ }^{26}$ Andreas Backhaus, "Fading Legacies: Human Capital in the Aftermath of the Partitions of Poland," European Historical Economics Society, no. 150 (March 2019): 1.
} 
An equally significant example in how important securing a nation's postal system was during the Nazi's occupation of the city of Danzig, which became a free city after the infamous treaty of Versailles. When the Nazis annexed Danzig, they focused their attack on the Danzig post office which further helps to illustrate the key role in which postal communications played in times of war. ${ }^{27}$ During this time-period a country needed not only to be able to communicate via telephone but also by telegraph, letter, and parcel post. To secure these apparatuses, an invading force must take full control over a nation's infrastructure. While highways and trains can be used to transport troops, they can also be used as weapons to disperse propaganda. Thus, the seizure of the Danzig post office helps to highlight the importance that the post office played during the Second World War.

\section{The Netherlands and the Aryan Question:}

The Third Reich's work to revise European history can be traced back to the early 1930s.

The Nazis supported academics who researched Westforschung, or the western borderlands between Germany, the Netherlands, and Belgium in order to find Germanic historical links between these countries. The German state would use this research later on in their occupation of these countries in order to highlight how the Dutch or Flemish people were actually of Germanic ancestry. ${ }^{28}$ In 1935 the SS wing called the Ahnenerbe, which was founded by Heinrich Himmler, that worked to help research and legitimize Aryan racial theory. ${ }^{29}$ The Ahnenerbe worked to

\footnotetext{
${ }^{27}$ Liberation Route Europe, "The Polish Post Museum,” accessed May 16, 2021, https://liberationroute.com/poland/spots/t/the-polish-post-museum.

${ }^{28}$ Geraldien von Frijtag Drabbe Künzel, Racial Science in Hitler's New Europe, 1938-1945, ed. Anton WeissWendt and Rory Yeomans (Lincoln, UNITED STATES: Nebraska Paperback, 2013), http://ebookcentral.proquest.com/lib/psu/detail.action?docID=1180186, 89.

29 “Ahnenerbe Documents Digital Collection | Ursinus College Research | Digital Commons @ Ursinus College,” accessed May 16, 2021, https://digitalcommons.ursinus.edu/ahnenerbe/.
} 
influence Dutch intellectuals and historians and helped to fund research which focused on the close ethnic and historical ties between the Germans and the Dutch. ${ }^{30}$

Nazi Germany invaded the Netherlands on May $10^{\text {th }}, 1940$. The Dutch resistance towards Nazi occupation was fierce, even after their capitulation, and the Germans implemented a civilian led administration. This comes in sharp contrast to Nazi policy in Poland, where the Polish people were ruled by a brutal military dictatorship and their nationhood was stripped away from them. Arthur Seyss-Inquart, a former chancellor of Austria would take the helm of this puppet administration. Almost immediately after Seyss-Inquart and his henchmen took control of the Netherlands, racial policies were instituted in the Netherlands. These laws hoped to keep the purity of the Dutch people by forbidding intermarriage between the Dutch and the Jews. An example of such legislation is the Verordnungsblatt für die besetzten Niederländischen Gebiete, which like the Nuremburg laws set precedents on racial purity. ${ }^{31}$ Further policy written by the German government worked to integrate the Netherlands into the Third Reich, by encouraging economic engagement between the Dutch and native Germans. The Third Reich rewrote the Dutch educational curriculum in order to highlight Germanic Dutch heritage which was a continuation of the Ahnenerbe. ${ }^{32}$ Despite Germanys attempts to 'peacefully' occupy the Dutch people, the Dutch revolted and created one of the largest resistance movements in occupied Europe, the largest resistance movement being that of Poland. Because of this Wehrmacht's became more directly involvement in the occupation of the Netherlands. ${ }^{33}$

\footnotetext{
${ }^{30}$ von Frijtag Drabbe Künzel, Racial Science in Hitler's New Europe, 90

${ }^{31}$ United States Office of Chief of Counsel for the Prosecution of Axis Criminality, Nazi Conspiracy and Aggression, 39.

${ }^{32}$ von Frijtag Drabbe Künzel, Racial Science in Hitler's New Europe, 92.

33 Jennifer L. Foray, “The 'Clean Wehrmacht' in the German-Occupied Netherlands, 1940-5," Journal of Contemporary History 45, no. 4 (2010): 768-9.
} 
What is even more fascinating is that German authorities worked to resettle the Dutch into areas in the East, including Poland, and the Ukraine, thus helping to illustrate that the Dutch were considered to be German-Aryans. This was a continuation of Nazi colonial policy which sought to Germanize the entirety of Europe and to eradicate any Jews, Slavs, Poles, Romani, or other Untermenschen from the European continent. The Dutch historian has researched this troubling aspect of Dutch history. She writes, "Between November 1941 and July 1944 several thousand Dutch workers went to the East voluntarily." 34 She continues, writing, "Apparently the Dutch recruits also saw themselves as soldiers who would, by their mere presence in the East, free this region from its political (i.e., Bolshevik) and ethnic (i.e., Slav and Jewish) enemies." ${ }^{35}$ While this segment of the population who did decide to go to the Ost Reich does not speak for the entirety of the Dutch people, it is important to note that they were given the opportunity to emigrate and be given land by the Third Reich. This land that had been stolen by the Nazis from ethnic Poles, Slavs, and Jews. This pattern of racial prioritization by the Nazi would repeat itself through the different national legions of Dutch, Norwegian, Danish and Flemish of SS troops that would fight for the fatherland. Before we examine Dutch and Polish stamp issues, I will examine Nazi art and propaganda, and how this was a key portion to the Nazi empire. This will better allow ourselves to critically analyze the stamps that the Third Reich issued.

\section{National Socialist Art and Propaganda:}

Through my analysis of the Nazi art discourse community, I found that there are two common themes utilized in Nazi art. The first is how art was used to create a new identity for German society that rejected individualism and embraced a collective identity. This type of art

\footnotetext{
${ }^{34}$ von Frijtag Drabbe Künzel, Racial Science in Hitler's New Europe, 97.

${ }^{35}$ Ibid.
} 
rejected the unique nature of Weimar art and other artistic styles such as dadaism, cubism, and expressionism. ${ }^{36}$ Furthermore, the Nazi's eradication and rejection of modernist culture was vital component of early Nazi politics. This is exemplified by the Kampfbund für deutsche Kultur. Local Kampfbund groups were established across Germany in order to counter what Nazi party elites saw as the disintegration of German culture. This fragmentation of German culture was caused by the highly liberal policies that were rooted in supposed Jewish and Bolshevik domination of culture. ${ }^{37}$ In many ways the art the Nazis sought to introduce into the public sphere was regurgitated artistic themes from the $19^{\text {th }}$ century. This art included pastoral peasant scenes, portraits of military leaders, and images of important battles. This art was easily consumed and did not require the viewer to think deeply about the motifs or obscure inclination of an artist in sharp contrast to modernist artistic movements such as dadaism. This reliance on previous artistic themes allowed the Nazis to affix themselves to historical culture. ${ }^{38}$ Thus by extension, this further allowed the Nazis to control the publics own understanding of art and culture. The preeminent Nazi art scholar Peter Adam, states,

The National Socialists discovered that art not only could carry a political message but was also a perfect medium for creating and directing desires and dreams. It was able to programs people's emotions and direct their behavior. ${ }^{39}$

The ministry of propaganda was directly involved in creating and distributing art, furthermore Nazi art found its way into almost every avenue of civilian life, with propaganda being produced for factories, canteens, and public parks.

Any historian would be remissed for not mentioning Josef Goebbels, the propagator of propaganda for the Third Reich from 1933-1945. In many ways it is difficult to detangle where

\footnotetext{
${ }^{36}$ Michael H. Kater, "Deconstructing Modernism," in Culture in Nazi Germany (Yale University Press, 2019), 1-53, https://doi.org/10.2307/j.ctvfc542q.6, 2-4.

${ }^{37}$ Ibid, 5.

${ }^{38}$ Ibid, 7.

${ }^{39}$ Adam, Peter. Art of the Third Reich. H.N. Abrams, 1992, 3-4
} 
the cult of propaganda began and the creation of art ended-but this is a question saved for another day. In order to understand the all-encompassing efforts that Goebbels had as the Minister of propaganda, it is necessary to highlight the extensive power he had within the Third Reich. In an article written in 1933, by a Nazi affiliated newspaper man, Hans Fritsche helps to detail the role in which Goebbels had on society. The excerpt reads,

The Propaganda Ministry is not bureaucratic administrative apparatus, but rather a spiritual center of power that stays in constant touch with the whole people on political, spiritual, cultural, and economic matters. It is the mouth and ear of the Reich government. ${ }^{40}$

Thus, propaganda was folded throughout the entirety of the Nazi establishment and German society. Fritsche helps to explain how Goebbels worked retool the radio industry, writing,

The radio, once a collection of private broadcasters in which the influence of the Reich, the states, political parties and private concerns battled, was united, cleansed and clearly organized. The radio was not only placed under National Socialist control, but also reconstructed on National Socialist lines. ${ }^{41}$

This total reworking of the radio industry is emblematic of how the Nazis' tentacles reached into all aspects of society. Thus, it is easy to see by extension how the stamps issued by the Nazis would directly exhibit the new aesthetics of the Third Reich.

In many ways this parallels Pye's own communication's theory, which highlights how a regime works to integrate itself into almost all aspects of society in order to solidify its control over a nation. This further helps to illustrate the important nature of Reichpost, as it was a public entity that needed to be controlled by the state. Art was either deemed Arteigene (racially pure) or Artfrende (alien) as detailed by the scholar Steinwies, who examines how Nazi art was economically controlled by the Reichsministerium für Volksaufklärung und Propaganda. ${ }^{42}$ Adam

\footnotetext{
${ }^{40}$ Hans Fritzsche, "Dr. Goebbels und sein Ministerium," in Hans Heinz Mantau-Sadlia, Deutsche Führer Deutsches Schicksal. Das Buch der Künder und Führer des dritten Reiches (Munich: Verlag Max Steinebach, 1934), pp. 330342.

${ }^{41}$ Ibid.

${ }^{42}$ Steinweis, Alan E. Art, Ideology \& Economics in Nazi Germany : The Reich Chambers of Music, Theater, and the Visual Arts. Chapel Hill: University of North Carolina Press, 1993, 103.
} 
furthermore explain the role that art had within Third Reich played, stating, "The art of this racially pure culture was to overcome class differences and forge the nation into an organic community of people following the same ideas. It was used to bind everyone individual to the nation." 43 This idea is incredibly useful in my own analysis of postage stamps, as it helps to highlight the essential role in which propaganda art played in the Third Reich.

The second important aspect of art was the revision of European culture through the rewriting of Germanic history. One core theme of art from the Nazi time period is the idea of Nordic mysticism. Nordic mysticism employs ideas of blot und boden, which ties national identity and soil together. Hitler believed that the Aryan people were the chosen people who would rule over European lands and who would lead the world into a peaceful future. Blot und boden's central theme is the enaction of Lebensraum, or the general expansion into Eastern European territory. However, the "historians" of the Third Reich worked hard to create a new collective Aryan identity. Their strategy, which at times was not coherent, allowed them to pick and choose people who could become part of the master race. This is where the idea of Nordic mysticism began to be employed by the ministry of the Third Reich, which tied classicalism and Norse mythology together. This allowed the ministry of propaganda to link German cultural identity to the creation of pyramids, as well as Grecian temples, as they fit into this supposed Nordic aesthetic. ${ }^{44}$ Furthermore, Nordic mysticism brought in themes of family, motherhood, sports, and heroism into the art that was created. Understanding these two important prongs, helps to guide how I will analyze stamps in this project.

\section{The Reichpost:}

\footnotetext{
${ }^{43}$ Adam, Art of the Third Reich, 16.

${ }^{44}$ Ibid, 23
} 
In 1932, Peter Paul Raimund Freiherr von Eltz-Rübenach, was named as the head of the Reichpost and was appointed by the then German Chancellor Hindenburg. Eltz-Rübenach considered himself to be a monarchist and at first supported the Nazi establishment. Under his tenure he created the postal advisory board and worked on postal agreements in different municipalities across Germany. However, Eltz-Rübenach was an ardent catholic and soon became an outspoken critic of the Third Reich's hostility to the catholic church, which led to his inevitable dismissal. ${ }^{45}$ Dr. Wilhelm Ohnesorge was the Reichpost minister from 1937-1945, where he worked to develop not only the post office but also the telegraph office, working to modernize the systems across Germany. ${ }^{46}$ Ohnesorge was an early party member of the NSDAP, joining in 1920. Ohnesorge primarily focused his work in the ministry was the research of espionage techniques, voice encryption, radar and nuclear physics. He was a researcher into the German nuclear bomb, where most of the academic research has focused on. ${ }^{47}$ It seems that the Reichpost ministry was focused on the development of an atomic bomb under the leadership of Ohnesorge. Due to limitations of the covid pandemic I was unable to access more archives regarding the Reichpost ministry.

Taking into account the previous analysis of Nazi art, and the aesthetics that were used I have selected numerous Reichpost stamps issued in Germany. The following examples help to

\footnotetext{
45 “Peter Paul Raimund Freiherr von Eltz-Rübenach,” accessed May 19, 2021, http://www.rheinischegeschichte.lvr.de/Persoenlichkeiten/peter-paul-raimund-freiherr-von-eltz-ruebenach/DE2086/lido/57c6a31620ab00.28222287.

46 “Dr. Wilhelm Ohnesorge Is Dead; Postal Minister in Hitler Cabinet: Specialized in Wireless," New York Times (1923-Current File), February 4, 1962, 115799601, ProQuest Historical Newspapers: The New York Times.

47 Thomas Stange, "Die Kernphysikalischen Ambitionen Des Reichspostministers Ohnesorge,” Berichte Zur Wissenschaftsgeschichte 21, no. 2-3 (1998): 159-74, https://doi.org/10.1002/bewi.19980210208,
} 
illustrate how Polish and Dutch stamp issues either differed or were similar to that of the Third

Reich. ${ }^{484950515253}$
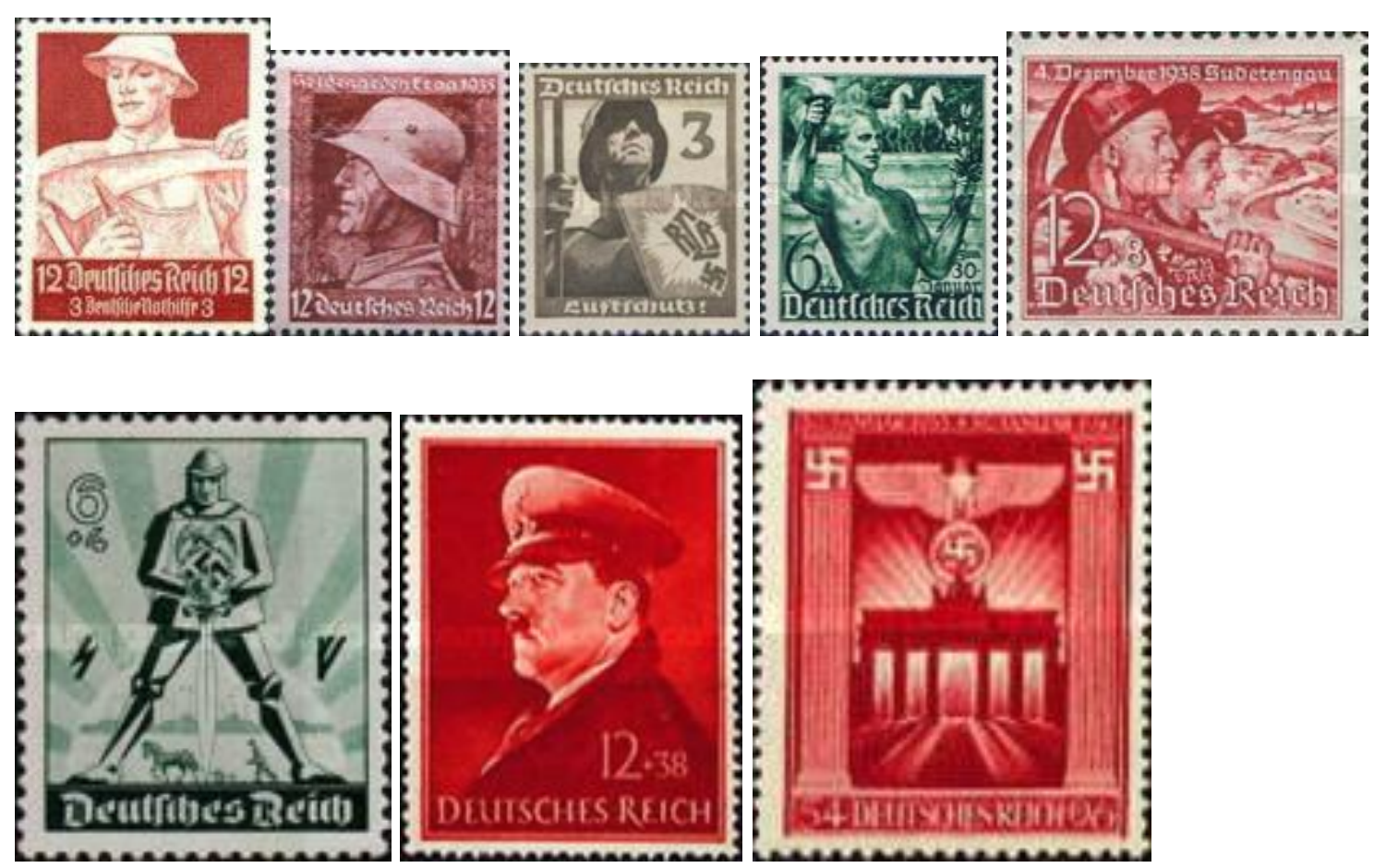

What we can see from these stamp issues are hypermasculine subject matter of these stamps. ${ }^{5455}$

In many ways the figures on the stamps resemble early German woodcuts, with their highly

stylized jawlines and bodies. I have included an image of $16^{\text {th }}$ century German woodcut from the

\footnotetext{
48 "German Empire - Postage Stamps - 1934 - Charity Stamps - Germany at Work," accessed May 21, 2021, https://www.stampworld.com/stamps/German-Empire/Postage-stamps/g0549//.

49 "German Empire - Postage Stamps - 1935 - Hero Memorial Day," accessed May 21, 2021, https://www.stampworld.com/stamps/German-Empire/Postage-stamps/g0562//.

50 "German Empire - Postage Stamps - 1937 - Air Defence," accessed May 21, 2021, https://www.stampworld.com/stamps/German-Empire/Postage-stamps/g0636//.

51 "German Empire - Postage Stamps - 1938 - The 5th Government Anniversary," accessed May 21, 2021, https://www.stampworld.com/stamps/German-Empire/Postage-stamps/g0653//.

52 "German Empire - Postage Stamps - 1938 - Sudetenland's Annexation," accessed May 21, 2021, https://www.stampworld.com/stamps/German-Empire/Postage-stamps/g0676//.

53 "German Empire - Postage Stamps - 1940 - May 1st," accessed May 21, 2021, https://www.stampworld.com/stamps/German-Empire/Postage-stamps/g0737//.

54 "German Empire - Postage Stamps - 1941 - The 52th Anniversary of the Birth of Adolf Hitler," accessed May 21, 2021, https://www.stampworld.com/stamps/German-Empire/Postage-stamps/g0764//.

55 "German Empire - Postage Stamps - 1943 - The 10th Anniversary of Assumption of Power," accessed May 21, 2021, https://www.stampworld.com/stamps/German-Empire/Postage-stamps/g0822//.
} 


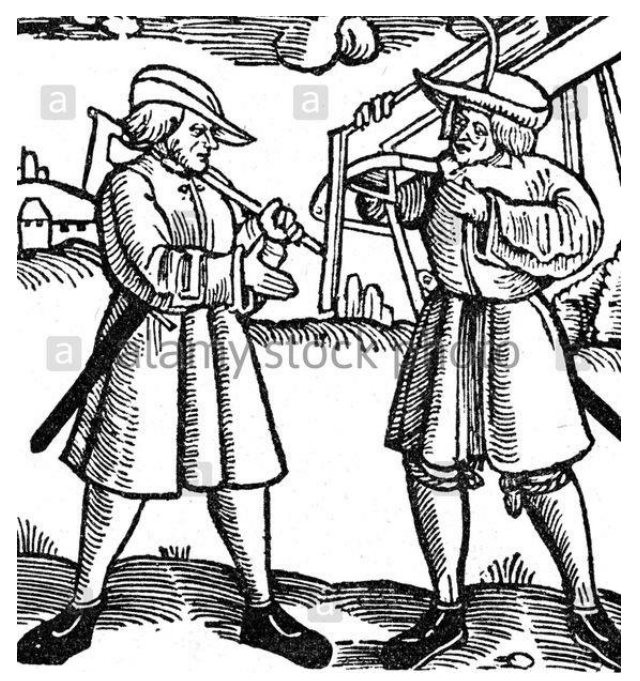

German Peasant war of $1525 .^{56}$ Look at the posturing of the man in the woodcut and the similarity between that stance to the stamp that depicts a soldier placing his sword into the ground.

Instead of relying on my expressionist or modernistic styles, the forms on these stamps are rigid, and rely on straight graphic lines. Most of the figures pictured in the stamps look into the distance. As emblemized in the stamp that depicts Hitler, his gaze is directed into the horizon, which highlights the Third Reich's vision of a new future for Germany. The men in these images also have extenuated jawlines, rigid muscles, and in many ways resemble a Grecian or Roman marble statue, thus harkening back to a previous time in order to legitimize their rule. So how do stamps issued in Poland compare to these German stamps?

\section{Polish Stamps:}

In 1940 the General Government released a series of stamps depicting prominent Polish buildings and landmarks, which was the first stamp issuance in Poland. ${ }^{57}$ What is most interesting about these stamps is that it helps to illustrate how the Germans were reimagining Polish national identity. Earlier in this essay we examined stamps that were reissued by the General Government and those stamps featured the Reichsadler. Similarly in these stamps the

\footnotetext{
${ }^{56}$ Alamy Limited, "Stock Photo - Agriculture, Peasants, Germany, 16th Century, Two Peasants during the Time of the German Peasants' War, 1525," Alamy, accessed June 9, 2021, https://www.alamy.com/stock-photo-agriculturepeasants-germany-16th-century-two-peasants-during-the-29123699.html.
} 
Reichsadler reappear in the upper right- or left-hand corner of the stamp. ${ }^{58}$ The Reichsadler, which through the cooption of a traditional Prussian coats of arms is used to help legitimize Nazi rule. This is done through the revision of history by the Nazis who coopted a traditional Germanic coat of arms and placed it on this General Government stamp. ${ }^{59}$ In the following stamps that are pictured below you will see a number of important and historic buildings in Poland. The buildings that are depicted on these stamps are the Florian Gate in Krakow, which was built in the $14^{\text {th }}$ century to protect the city from Turkish invaders. ${ }^{60}$ The next stamp is the Baszta Sandomierska, which is part of a castle that was built in the $15^{\text {th }}$ century and is located in Krakow. The green stamp depicts the Brama Krakowska or the Krakow Gate in Lubin, which was erected in the $14^{\text {th }}$ century. The first stamp in the second row depicts University Court of Jagiellonian University in Krakow, which was Poland's first University and was founded in 1364. The black stamp illustrates Dominican Church in Krakow, which was built in 1233 . The red stamps shows Wawel Castle which was created in the $12^{\text {th }}$ century. The first stamp in the third row depicts the Kościół Wniebowzięcia Najświętszej Maryi Panny Zwycięskiej (the Church of the Assumption Virgin Mary) in Lublin, which was founded in $1396 .{ }^{61}$ The dark gray stamp shows the Cloth Hall Krakow which was built in the $14^{\text {th }}$ century. The final stamp in the third row depicts the Town Hall Tower in Krakow which was built in the $14^{\text {th }}$ century. The first stamp in the final row of stamps illustrates Castle Court, which is part of the Wawel Castle, which is in Krakow. The aubergine-colored stamp is of Saint Mary's Basilica in Krakow, which

\footnotetext{
58 “Nazi Eagle," Anti-Defamation League, accessed May 20, 2021, https://www.adl.org/education/references/hatesymbols/nazi-eagle.

59 "General Government - Postage Stamps - 1940 - Buildings," accessed May 20, 2021, https://www.stampworld.com/stamps/General-Government/Postage-stamps/g0040//.

60 “St Florian's Gate - Magiczny Kraków," accessed June 9, 2021, https://www.krakow.pl/english/instcbi/41907,inst,4889,324,instcbi.html.

61 "History - Rector's Church Of the Assumption of the Blessed Virgin Mary Victorious in Lublin," accessed June 9, 2021, https://pobrygidkowski.pl/pl/historia.html.
} 
was founded in the $14^{\text {th }}$ century. The final stamp of this series is the Brühl palace in Warsaw,

which was built in the $17^{\text {th }}$ century. Unfortunately, this palace was destroyed by the Nazis during the Warsaw uprising of $1944 .^{6263}$
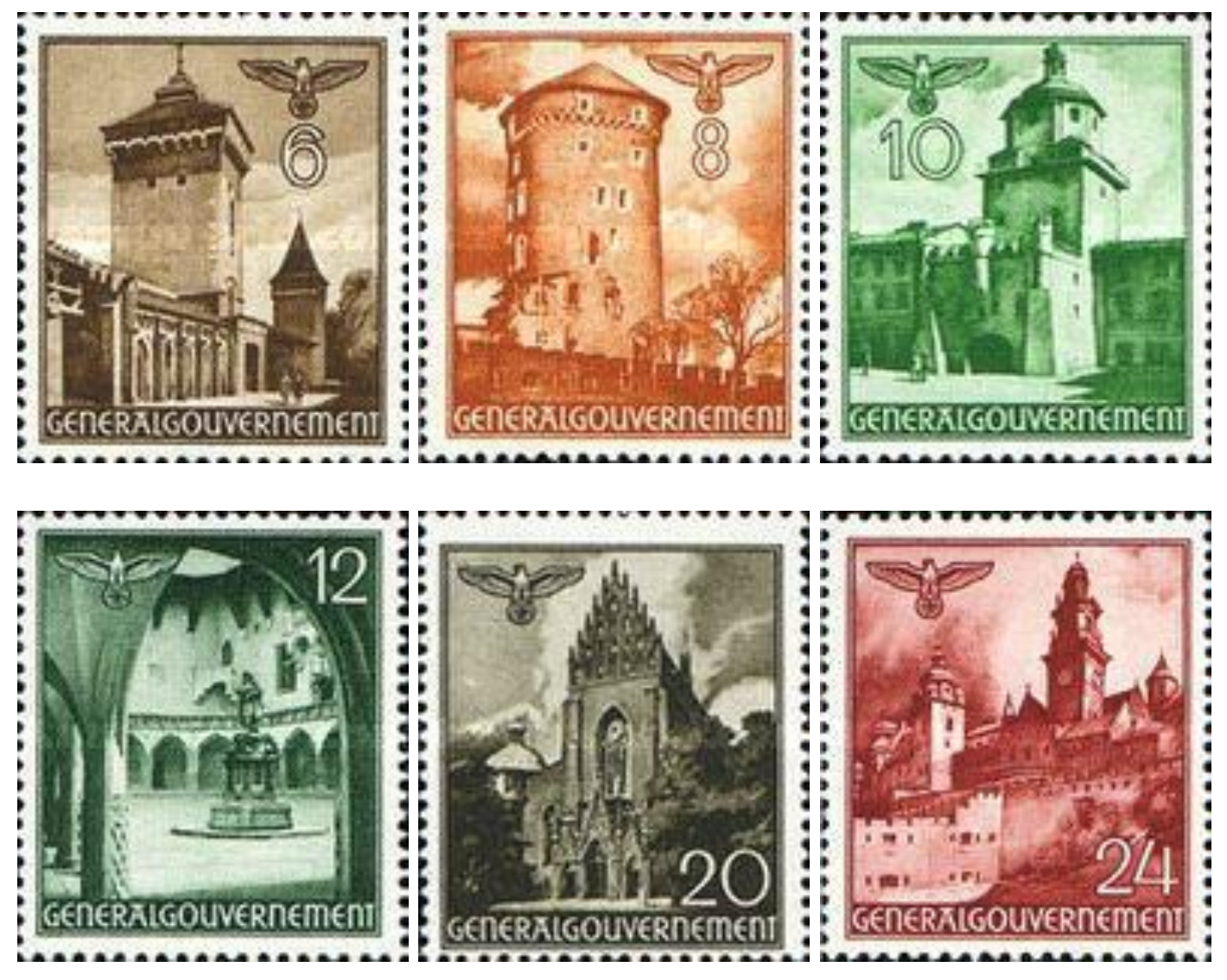

\footnotetext{
${ }^{62}$ Please see Appendix 1 and 2 to see maps of the general government in Poland during the Second World War. ${ }^{63}$ Important historical note, during the Warsaw uprising, a post office was created by in the Warsaw ghetto to distribute mail. More information regarding this can be found in Warsaw 1944 by Alexandra Richie.
} 

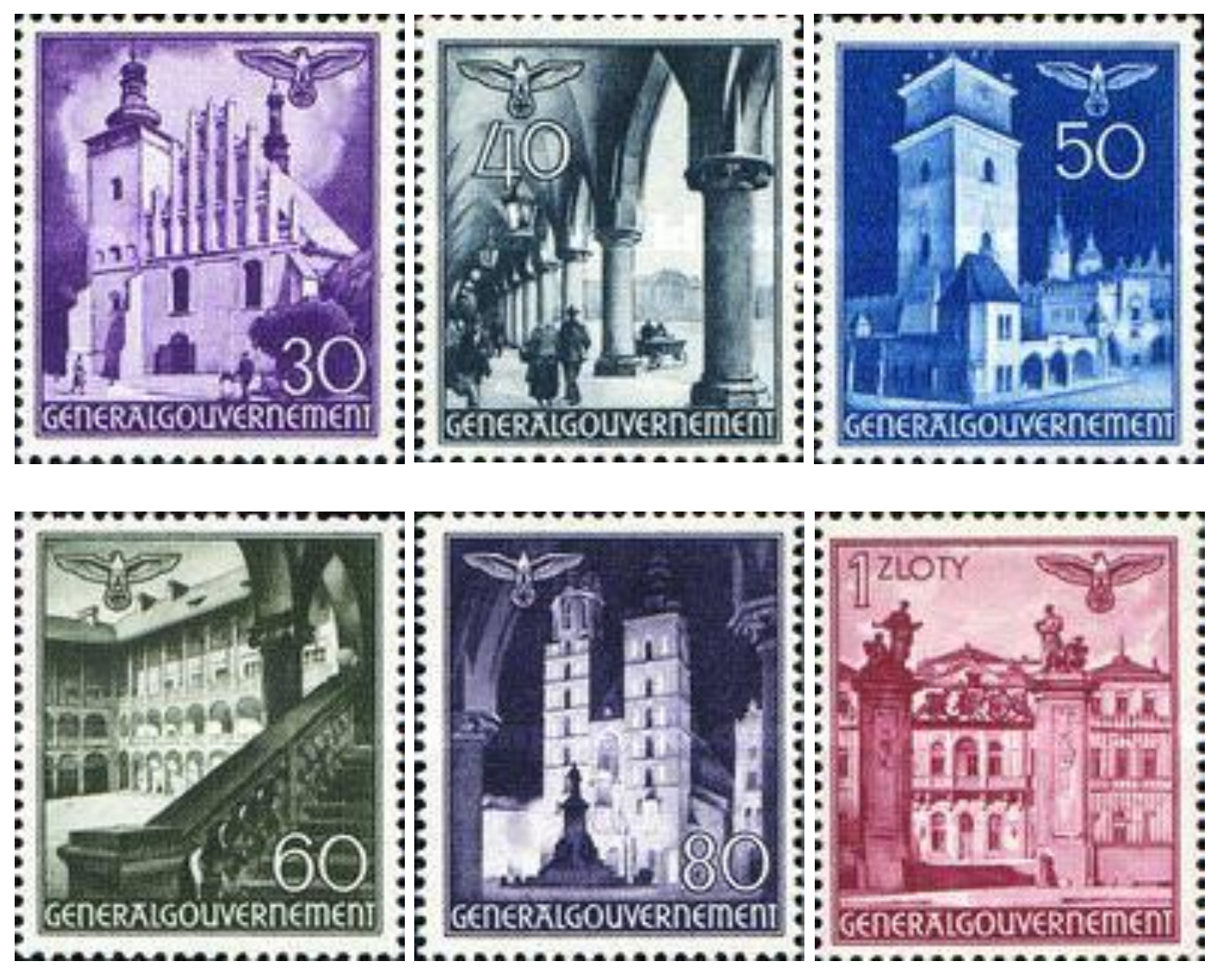

What we see from these Polish stamp issues is that all of these cultural monuments are in the cities of Lubin, Krakow, and Warsaw. While generalized trends from the end of the $19^{\text {th }}$ to the beginning of the $20^{\text {th }}$ century point to more populations moving towards more urban areas, there was still a large portion of the Polish people who lived in the country. ${ }^{64}$ These stamps ignore cultural monuments in the countryside. All of the buildings, besides the Brühl palace were built before the $15^{\text {th }}$ century. The period between the $13^{\text {th }}-16^{\text {th }}$ centuries is commonly known as the golden age for Polish cultural history where Poland participated in the European renaissance. Thus, the buildings that the Nazis are highlighting in these stamps are harkening back to a gilded age, an age that the Nazis wanted to reestablish through their occupation of Poland. These buildings also fit into the Nazi architectural aesthetic, which sought to incorporate militaristic

\footnotetext{
${ }^{64}$ Please see Appendix 2 for Polish demographic chart.
} 
and gothic aspects into the buildings that were created. The palatial and brutalist qualities of such Nazi architecture can be seen in Nuremberg Rally Grounds, which has now been turned into a museum. Many historians and theorists have focused on how architecture can be used as a political tool. The geographical historian Hagan writes,

This approach views the built environment as a 'text', which can be read to discern underlying social, economic, and political relationships of dominance and resistance. In addition to elucidating the political and cultural motivations driving the architectural inscription of 'official' or dominant narratives into urban space, this research has often emphasized how these official iconographies are negotiated, resisted, or subverted. ${ }^{65}$ Hagan's argument fits nicely into what I am myself arguing on the significant nature of these

Polish stamp issues. While outwardly they might not exhibit traditional approaches to propaganda, the Nazis are enforcing their own idea of Polish identity onto the Polish people by hoping to rekindle a previously lost gilded age through their occupation. This was the Third Reich's first stamp issuance in Poland, and the German's purposely used Polish architecture to begin to help rewrite Poland's narrative. The Polish people themselves might not be able to be Germanized, but its buildings could be.

\section{Dutch Legion Stamps:}

During the Second World War there were SS Divisions that were set up in occupied European territories. For many people, this painful history has led their history to be ignored, as the politics of collaboration are complicated and difficult to untangle especially in an after-war setting. The historian Gingreich highlights this fascinating moment in history, writing,

\footnotetext{
65 Joshua Hagen, "Architecture, Symbolism, and Function: The Nazi Party's 'Forum of the Movement,"” Environment and Planning D: Society and Space 28, no. 3 (June 1, 2010): 397-424, https://doi.org/10.1068/d2206, 397.
} 
As this study will show, the recruitment of Germanic volunteers in fact developed as an expression of SS racial and political thought and ambition. The decision to recruit nonGermans of "Germanic blood" for the Waffen SS was inextricably connected with the dream of radically transforming the face of Europe according to Nazi concepts of race and ethnicity. According to SS thought, the Germanic peoples of Europe were essentially identical to the Germans from a racial standpoint. ${ }^{66}$

In order to help fund these SS divisions, the Third Reich created postal stamp issues in order to help provide funds for these troops. Stamps being issued to fundraise for various causes has been a central theme in postal history. These stamps are often refereed as a semi-postals and are used in order to fundraise for a specific cause or an event. Semi-postals that had been issued since at least the 1890 s and are still used today. ${ }^{67}$ These legion stamps were not only issued in Netherlands but also other Germanized countries, including Belgium, Norway, Denmark, and Norway. ${ }^{68}$

The Dutch SS Legion or the SS Niederlande recruitment began after occupation by the German forces. Due to the Third Reich fighting wars on more than one front, more manpower was needed to aid in the war effort. This legion fought in near Leningrad in 1941, in 1942-1943 they participated in the siege of Leningrad, and in mid-1943 they were sent to fight in Yugoslavia before its retreated back into Germany where they fought until capitulation. ${ }^{69}$ The stamps that were issued depict a highly Germanic looking soldier. ${ }^{70}$

\footnotetext{
${ }^{66}$ Mark P Gingerich, “Waffen SS Recruitment in the 'Germanic Lands,' 1940-1941,” The Historian 59, no. 4 (June 1, 1997): 815-30, https://doi.org/10.1111/j.1540-6563.1997.tb01377.x. 815.

67 "Alphabetilately: USPS Semi-Postal Stamps," accessed May 20, 2021, https://alphabetilately.org/G3.html.

68 "Dutch Legion | GermanStamps.Net," accessed May 20, 2021, https://www.germanstamps.net/tr-legion-nd/. ${ }^{69}$ Ibid.

70 "Netherlands - Postage Stamps (1940 - 1949) - Page 2," accessed April 17, 2021, https://www.stampworld.com/stamps/Netherlands/Postage\%20stamps/1940-1949?user=474104\&page=2
} 


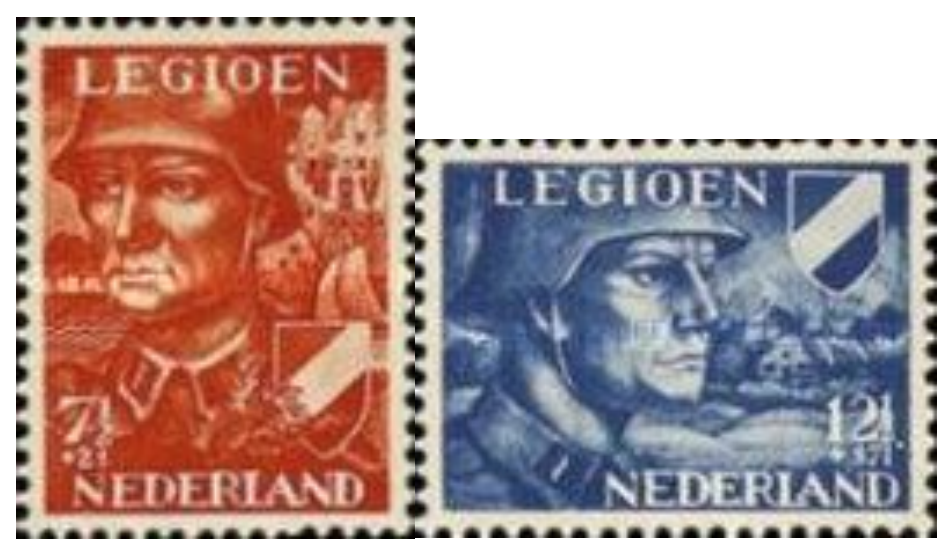

In the background imagery of both of these stamps, we see typified Dutch architecture with the traditional parapet on the buildings. The soldier, with his striking cheekbones, looks off into the distance of the image, hinting at the future progress that would be seen under the Third Reich. The positioning of the soldiers helps indicate that he is protecting his homeland. These legion stamps are in many ways parallel to traditional Nazi stamps issued in the Third Reich. These stamps also further help to romanticize the pastoral countryside. This romanization of the countryside is important as it highlight policies of German resettlement and Lebensraum that 5,000 Dutch settlers participated in. The hypermasculinity that exudes from the soldiers depicted in these images, as well as the regional landmarks help to highlight and distinguish Nazi policy within the Netherlands. There is no demographic data on how much these stamps were used, but there are examples of them in circulation. Other SS legion stamps issued by these divisions, are also similar to Dutch legion stamp issues. For instance, the Norwegian stamp issues present a highly stylized aryan soldier fighting behind a Norwegian flag. ${ }^{71}$

\footnotetext{
71 “Norwegian Legion | GermanStamps.Net,” accessed May 20, 2021, https://www.germanstamps.net/tr-legion-no/.
} 


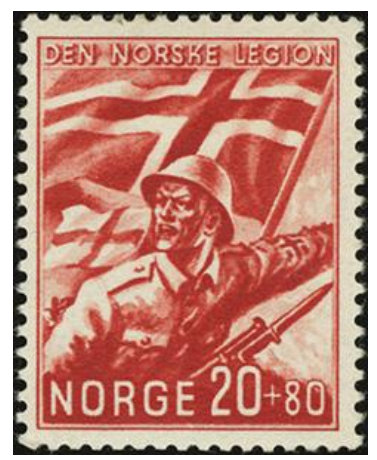

What is stridently clear in these stamp issues of organized nations, is that their cultural and national identity was still being preserved, while in the Polish stamp issues, we see the erasure of a nation.

Throughout the course of this essay, we have examined how the Nazis used the Reichpost in the Netherlands and Poland as an extension of their propaganda wing. They used these stamps in order to convey their racial and colonial policy. In Poland, they used architectural stamp issues to highlight their occupation of the country and the Germanization of the cultural landmarks, while in SS Legion stamps we see Dutch heritage being celebrated in semi-postal stamps that were issued in order to help fundraise for the Dutch SS Division. Historians have ignored these tiny vestiges of propaganda and have failed to look at how stamps can be used to influence a populace's opinion subconsciously or consciously. The goal of this essay is not only to highlight the importance of studying stamps and their manifestations to historical trends, but also to introduce a new field of study— postal history. Like many historical disciplines, postal history brings in anthropology, sociology, history, art history, political science, economics, and many other disciplines together. Stamps can be used to track a nations stability in times of war, track a countries civil rights record, or highlight injustices of the past. They can also be used to fundraise for a wide variety of causes, which is continually being used in the United States of America to bring awareness to cancer, domestic violence, and endangered species. It is time for academia to focus on postal history and the prominent part it has in history. 


\section{Appendixes:}

Appendix 1: ${ }^{72}$

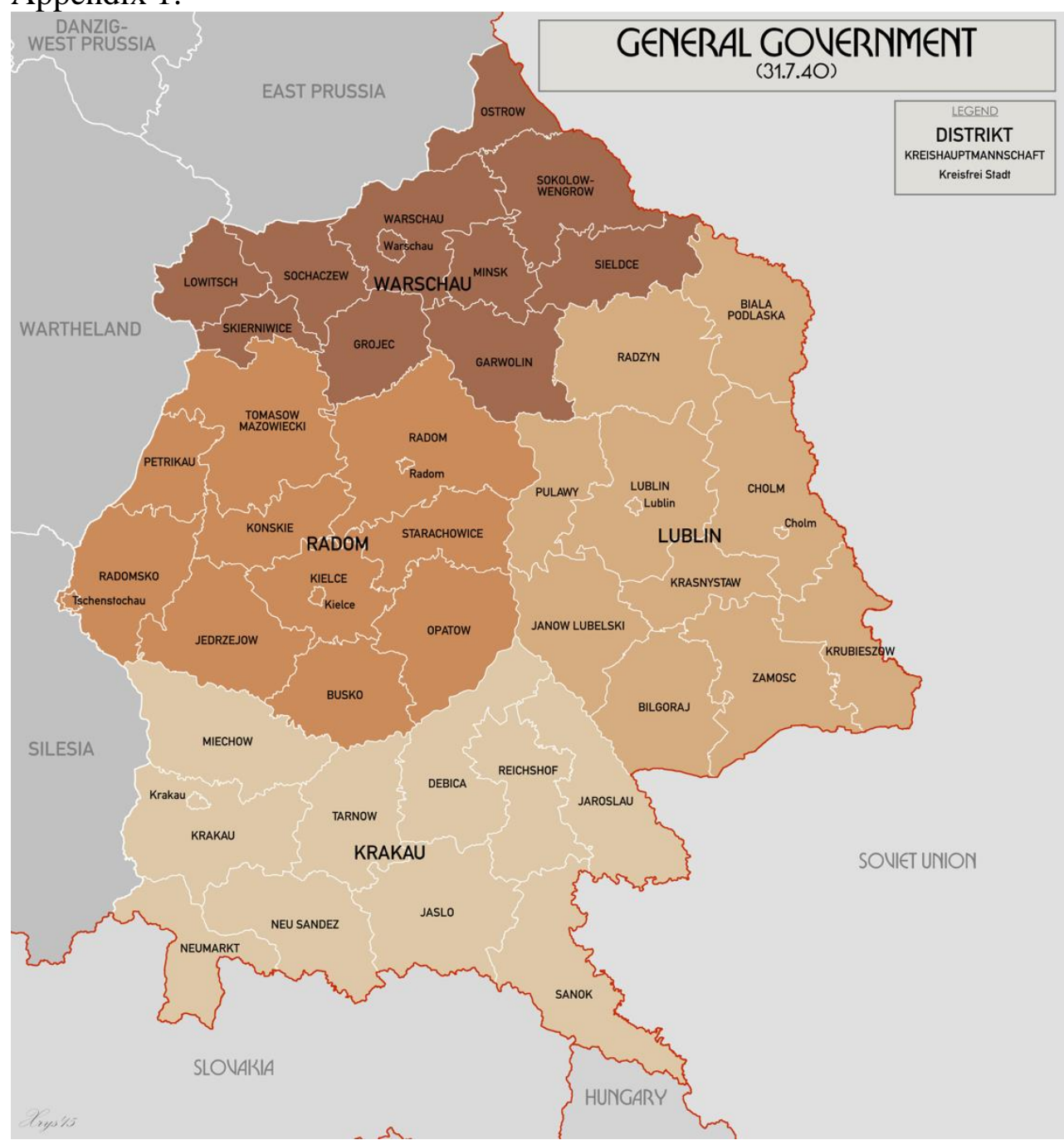

Appendix 2:73

72 “General Government," in Wikipedia, April 10, 2021, https://en.wikipedia.org/w/index.php?title=General_Government\&oldid=1017025133.

73 "General Government," in Wikipedia, April 10, 2021, https://en.wikipedia.org/w/index.php?title=General_Government\&oldid=1017025133. 


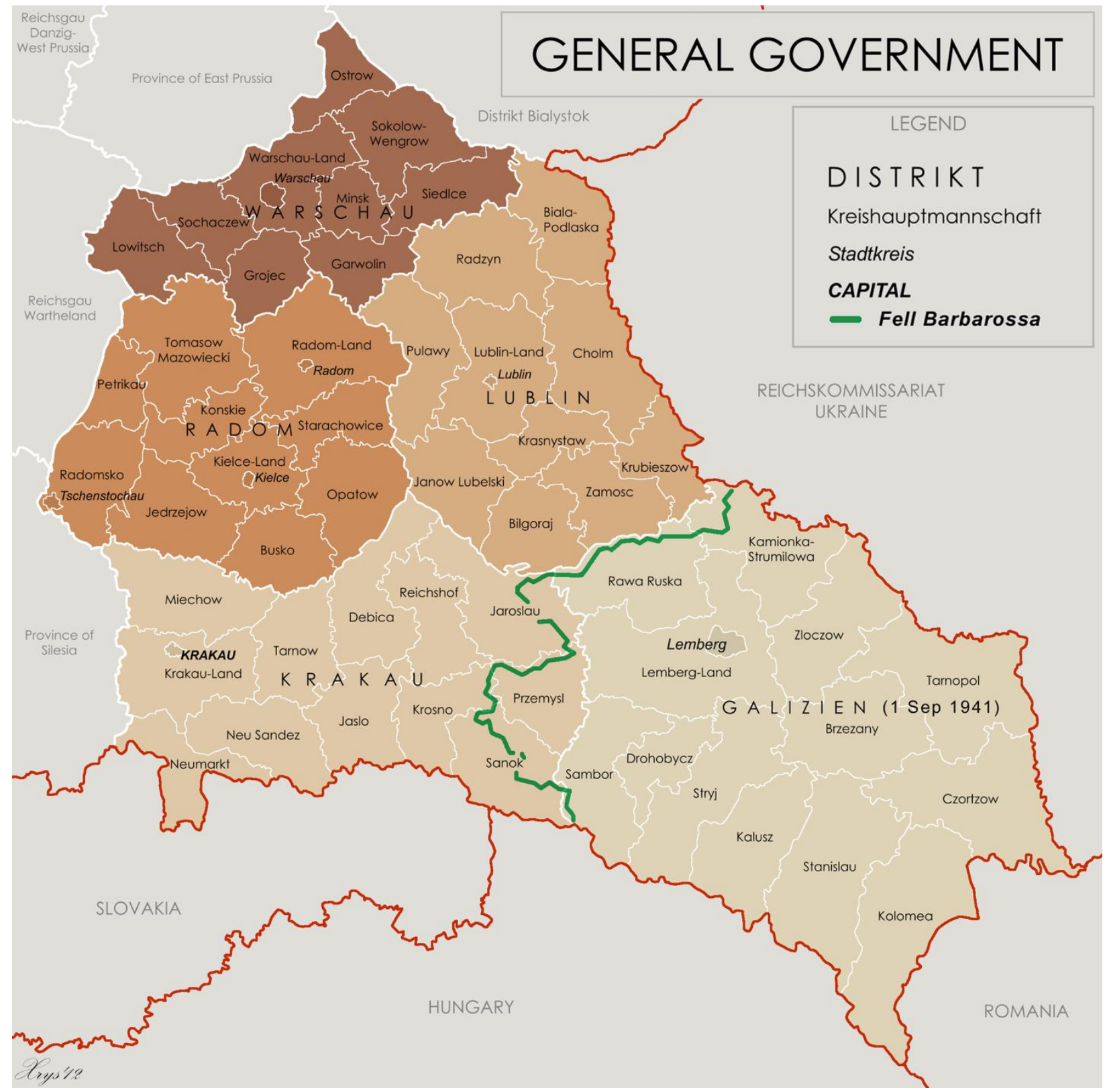

Appendix $3:^{74}$

${ }^{74}$ POLISH ACADEMY OF SCIENCES, “THE POPULATION OF POLAND," POLISH ACADEMY OF SCIENCES COMMITTEE FOR DEMOGRAPHIC STUDIES, n.d., 1975. 


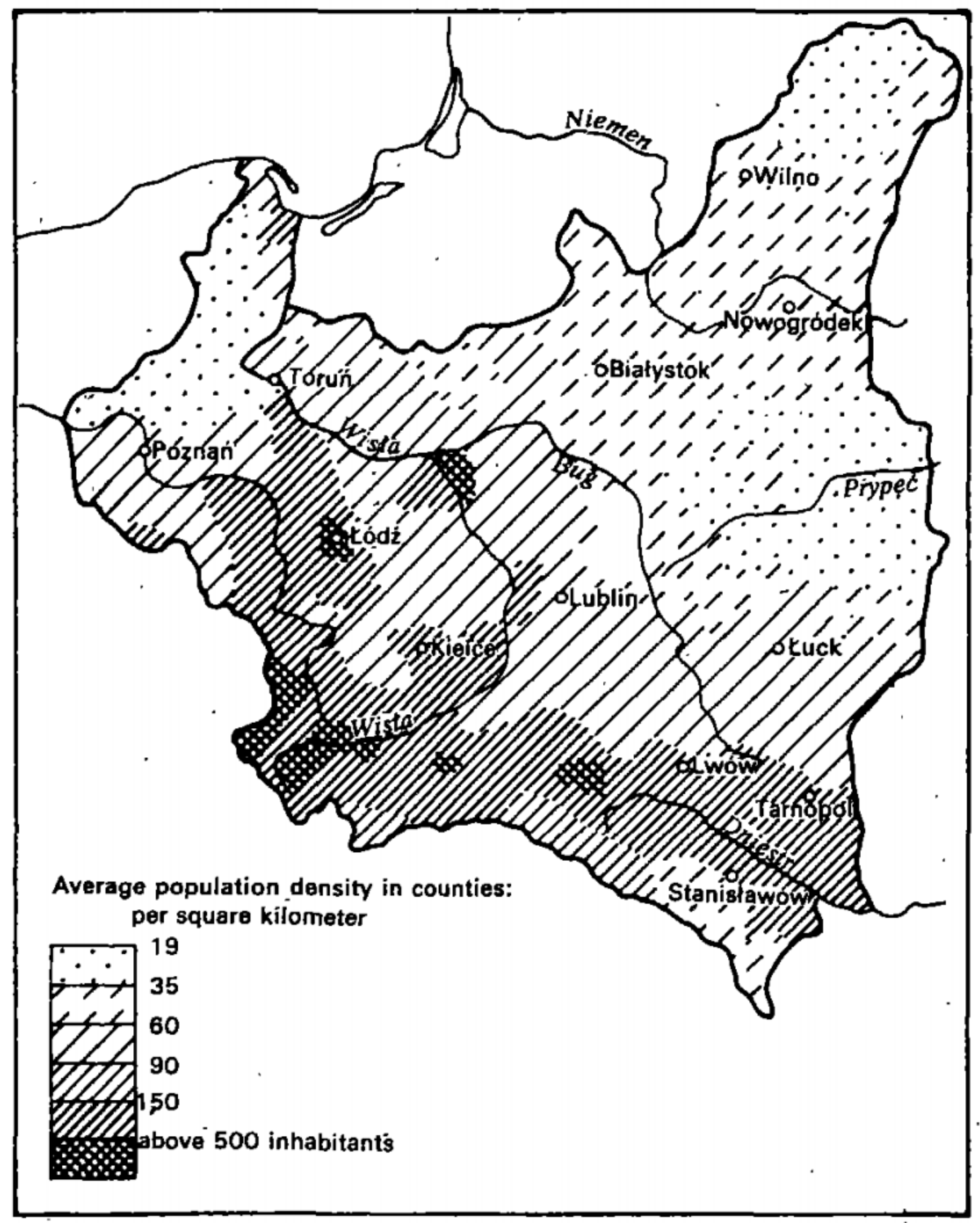




\section{Bibliography:}

All Stamps. "Nazi Party Congress 1936," n.d.

https://www.allstamp.net/product/GE00047980.html.

“Alphabetilately: USPS Semi-Postal Stamps," accessed May 20, 2021, https://alphabetilately.org/G3.html.

Alamy Limited, "Stock Photo - Agriculture, Peasants, Germany, 16th Century, Two Peasants during the Time of the German Peasants' War, 1525," Alamy, accessed June 9, 2021, https://www.alamy.com/stock-photo-agriculture-peasants-germany-16th-century-two-peasantsduring-the-29123699.html.

Allen, Kieran., "The Sociologist of Empire," in Weber, 2nd ed., Sociologist of Empire (Pluto Press, 2017), 15-31, https://doi.org/10.2307/j.ctt1v2xw28.5.

“Ahnenerbe Documents Digital Collection | Ursinus College Research | Digital Commons @ Ursinus College," accessed May 16, 2021, https://digitalcommons.ursinus.edu/ahnenerbe/.

Backhaus, Andreas. "Fading Legacies: Human Capital in the Aftermath of the Partitions of Poland," European Historical Economics Society, no. 150 (March 2019).

Dost, Frederick. World Maritime History Lessons Through Postage Stamps. Frederick E. Dost, 2015.

“Dutch Legion | GermanStamps.Net," accessed May 20, 2021, https://www.germanstamps.net/trlegion-nd/.

"Dr. Wilhelm Ohnesorge Is Dead; Postal Minister in Hitler Cabinet: Specialized in Wireless," New York Times (1923-Current File), February 4, 1962, 115799601, ProQuest Historical Newspapers: The New York Times.

Eisenberg, Ronald. 2002. The Jewish world in stamps: 4000 years of Jewish civilization in postal stamps. Rockville, Md: Schreiber Pub.

Fritz, Stephen. "Emergence of the Idea," in The First Soldier, Hitler as Military Leader (Yale University Press, 2018), 18-38, https://doi.org/10.2307/j.ctv7cjw22.8.

Friedländer, Saul. Nazi Germany and the Jews: The Years of Persecution, 1933-1939 (New York, N.Y.: Harper Perennial, 1997).

Furber, David. "Near as Far in the Colonies: The Nazi Occupation of Poland," The International History Review 26, no. 3 (2004).

Foray, Jennifer L., "The 'Clean Wehrmacht' in the German-Occupied Netherlands, 1940-5," Journal of Contemporary History 45, no. 4 (2010). 
Fritzsche, Hans. "Dr. Goebbels und sein Ministerium," in Hans Heinz Mantau-Sadlia, Deutsche Führer Deutsches Schicksal. Das Buch der Künder und Führer des dritten Reiches (Munich: Verlag Max Steinebach, 1934), pp. 330-342.

Hitler, Adolf. Murphy, James Vincent, and Carruthers, Bob. Mein Kampf : The Official 1939 Edition. Hardback ed. Arden, Warwickshire: Coda Books, 2011.

Henrik, Eberle, Victoria Harris, and Steven Rendall. Letters to Hitler. Cambridge; Malden, Ma.: Polity, 2012.

"History - Rector's Church Of the Assumption of the Blessed Virgin Mary Victorious in Lublin,” accessed June 9, 2021, https://pobrygidkowski.pl/pl/historia.html.

Hagen, Joshua. "Architecture, Symbolism, and Function: The Nazi Party's 'Forum of the Movement,"' Environment and Planning D: Society and Space 28, no. 3 (June 1, 2010): 397424, https://doi.org/10.1068/d2206.

Gates, Robin Elliot. "Philatelic Propaganda: A Case Study-Border Changes in Eastern Europe, 1938-1941.” Smithsonian Institution Scholarly Press, 2010.

“German Empire - Postage Stamps - 1935 - Hero Memorial Day,” accessed May 21, 2021, https://www.stampworld.com/stamps/German-Empire/Postage-stamps/g0562//.

“German Empire - Postage Stamps - 1937 - Air Defence," accessed May 21, 2021, https://www.stampworld.com/stamps/German-Empire/Postage-stamps/g0636//.

"German Empire - Postage Stamps - 1938 - The 5th Government Anniversary," accessed May 21, 2021, https://www.stampworld.com/stamps/German-Empire/Postage-stamps/g0653//.

"German Empire - Postage Stamps - 1938 - Sudetenland's Annexation," accessed May 21, 2021, https://www.stampworld.com/stamps/German-Empire/Postage-stamps/g0676//.

“German Empire - Postage Stamps - 1940 - May 1st," accessed May 21, 2021, https://www.stampworld.com/stamps/German-Empire/Postage-stamps/g0737//.

"German Empire - Postage Stamps - 1941 - The 52th Anniversary of the Birth of Adolf Hitler," accessed May 21, 2021, https://www.stampworld.com/stamps/German-Empire/Postagestamps/g0764//.

"German Empire - Postage Stamps - 1943 - The 10th Anniversary of Assumption of Power," accessed May 21, 2021, https://www.stampworld.com/stamps/German-Empire/Postagestamps/g0822//.

"General Government - Postage Stamps - 1939 - German Empire Postage Stamps Surcharged \& Overprinted 'Deutsche Post OSTEN,'” accessed May 16, 2021, https://www.stampworld.com/stamps/General-Government/Postage-stamps/g0001//. 
"German Empire - Postage Stamps - 1934 - Charity Stamps - Germany at Work," accessed May 21, 2021, https://www.stampworld.com/stamps/German-Empire/Postage-stamps/g0549//.

“General Government - Postage Stamps - 1940 - Buildings," accessed May 20, 2021, https://www.stampworld.com/stamps/General-Government/Postage-stamps/g0040//.

Gingerich, Mark P,"Waffen SS Recruitment in the 'Germanic Lands,' 1940-1941,” The

Historian 59, no. 4 (June 1, 1997): 815-30, https://doi.org/10.1111/j.1540-6563.1997.tb01377.x.

Jeffrey, Keith. "Crown, Communication and the Colonial Post: Stamps, the Monarchy and the British Empire." The Journal of Imperial and Commonwealth History 34, no. 1 (March 2006): 45-70. https://doi.org/10.1080/03086530500411290.

Klug, Janet. "Surcharges and Overprints Make a Difference," Linns Stamp News, accessed May 1, 2021, https://www.linns.com/news/postal-updates-page/stamp-collectingbasics/2002/june/surcharges-and-overprints-make-a-difference-.html.

Kater, Michael., "Deconstructing Modernism," in Culture in Nazi Germany (Yale University Press, 2019), 1-53, https://doi.org/10.2307/j.ctvfc542q.6.

Liberation Route Europe, “The Polish Post Museum,” accessed May 16, 2021, https://liberationroute.com/poland/spots/t/the-polish-post-museum.

"Nazi Eagle," Anti-Defamation League, accessed May 20, 2021, https://www.adl.org/education/references/hate-symbols/nazi-eagle.

"Netherlands - Postage Stamps (1940 - 1949) - Page 2," accessed April 17, 2021, https://www.stampworld.com/stamps/Netherlands/Postage\%20stamps/1940$\underline{1949 \text { ? user }=474104 \& \text { page }=2}$

"Norwegian Legion | GermanStamps.Net," accessed May 20, 2021, https://www.germanstamps.net/tr-legion-no/.

Mellville, Fred,. The Postage Stamp in War: Illustrated Edition. London: Echo Library, 2015. Moore, Albert . 2003. Postal propaganda of the Third Reich. Atglen, PA: Schiffer Military History.

"Poland - Postage Stamps - 1938 - The 20th Anniversary of the Republic," accessed June 9, 2021, https://www.stampworld.com/stamps/Poland/Postage-stamps/g0295//.

Pye, Lucian W. Communications and Political Development. (SPD-1) (Princeton, UNITED STATES: Princeton University Press, 1963), http://ebookcentral.proquest.com/lib/psu/detail.action?docID=4339554. 
Steinweis, Alan E. Art, Ideology \& Economics in Nazi Germany : The Reich Chambers of Music, Theater, and the Visual Arts. Chapel Hill: University of North Carolina Press, 1993, 103.

"Peter Paul Raimund Freiherr von Eltz-Rübenach," accessed May 19, 2021, http://www.rheinische-geschichte.lvr.de/Persoenlichkeiten/peter-paul-raimund-freiherr-von-eltzruebenach/DE-2086/lido/57c6a31620ab00.28222287.

Schnurre, "Foreign Office Memorandum," July 20, 1939, Purdue, http://www.ibiblio.org/pha/nsr/nsr-01.html\#2.

"St Florian's Gate - Magiczny Kraków," accessed June 9, 2021, https://www.krakow.pl/english/instcbi/41907,inst,4889,324,instcbi.html.

Stange, Thomas Stange. "Die Kernphysikalischen Ambitionen Des Reichspostministers Ohnesorge," Berichte Zur Wissenschaftsgeschichte 21, no. 2-3 (1998): 159-74, https://doi.org/10.1002/bewi.19980210208.

Rogowski, Jon C, John Gerring, and Lee Cojocaru, "Infrastructure and Development: Evidence from Postal Systems," 2017.

Ribbentrop, Joachim Ribbentrop. "The Reich Foreign Minister to the German Ambassador in the Soviet Union (Schulenburg)," June 21, 1941, Purdue, http://www.ibiblio.org/pha/nsr/nsr09.html\#23.

"The Law for the Safegaurd of German Honor," September 15, 1935, http://multivu.prnewswire.com/mnr/archives/45819/docs/45819-TranslationBlood_and_Honor.pdf.

The Molotov-Ribbentrop Pact," August 23, 1939, Internet Modern History Sourcebook, https://sourcebooks.fordham.edu/mod/1939pact.asp.

"The State Secretary in the German Foreign Office (Weizsäcker) to the German Ambassador in the Soviet Union (Schulenburg)," June 30, 1939, Purdue, http://www.ibiblio.org/pha/nsr/nsr01.html\#2.

United States Office of Chief of Counsel for the Prosecution of Axis Criminality, Nazi Conspiracy and Aggression (U.S. Government Printing Office, 1946).

United States Office of Chief of Counsel for the Prosecution of Axis Criminality, Nazi Conspiracy and Aggression. 
von Frijtag Drabbe Künzel ,Geraldien. Racial Science in Hitler's New Europe, 1938-1945, ed. Anton Weiss-Wendt and Rory Yeomans (Lincoln, UNITED STATES: Nebraska Paperback, 2013), http://ebookcentral.proquest.com/lib/psu/detail.action?docID=1180186. 